УДК: $745.03,745.55,745.521$

ББК: 85.12

A43

DOI:10.18688/aa166-4-32

Silvia Leggio

\title{
Relics in Cortona between Byzantium and Italy: The Case of the Church of St. Francis
}

In the year 1245, a few months before Pope Innocent IV (1243-1254) declared Frederick II deposed, a Franciscan friar received from the city municipality of Cortona a plot of land in an area known as Balneum Reginae [16, pp. 135-136]; there he started the construction of an intramural church dedicated to Saint Francis ${ }^{1}$, which nowadays houses a small but important collection of relics. Besides the fragment of the True Cross, preserved in the renowned Byzantine reliquary (Ill. 95), the other three relics related to the memory of Saint Francis belong to this sacred treasury: the cassock (Ill. 96) and evangeliary (Ill. 97) used by the Saint of Assisi, and his mortuary pillow (Ill. 98).

According to the tradition, they arrived in Cortona thanks to the effort of one of the most controversial historic figures in the early years of Franciscanism, Friar Elias (ca. 1180-1253) (Fig. 1), the founder of the church of Cortona itself, disciple and companion of Saint Francis, Minister General of the Franciscan Order between 1232 and 1239, and Frederick II's friend and supporter ${ }^{2}$. Some internal conflicts in the Order and his closeness to the Emperor led to his excommunication declared in 1240 by the Pope. After that Elias definitively switched to the side of the "enemy of the Church", becoming one of his most trusted confidant. Finally, in the last years of his life he settled in the Ghibelline city of Cortona ${ }^{3}$, where he decided to build the Church of St. Francis that was meant to be the repository of the relics which are the subject of this paper. Willing to create a Franciscan alternative to Assisi in Cortona, as Refice once pointed out [35, p. 157], he made use of the strong religious value of this sacred collection that, however, has been mostly neglected in academic research.

Despite the fact that scholars produced a rich bibliography regarding the Byzantine staurotheke ${ }^{4}$, they focused little interest on other items. The pillow was an exception: it was to know a moment of more intense critical debate at the beginning of the $20^{\text {th }}$ century $[12 ; 13 ; 19$;

In 1254 religious services were held in the church [24, p. 53], although it was consecrated over a century later, in 1375 [16, p. 138].

2 We don't know if Elias was born in Cortona or Assisi, and also the exact time and place of his joining the Saint are uncertain; it might have been in 1211, when Francis of Assisi came to Cortona and his preaching attracted a community of friars, who settled nearby in an area called Le Celle: a small hermitage was erected there and it briefly housed Saint Francis himself. Monks remained at the site for nearly a century [24, p. 45]. For the biography of Friar Elias and issue concerning his being subject of disapproval, see $[5 ; 6 ; 17]$.

The most complete, although outdated, overview of the historical events concerning Cortona during the $13^{\text {th }}$ century can be found in [28].

$4 \quad$ Most recently $[25 ; 26]$ (with previous bibliography). 
36], and then in 1987, when Devoti tried to provide stylistic and artistic connections with other similar artifacts [15]. Finally, on the $750^{\text {th }}$ anniversary of the death of Friar Elias, in 2003, an in-depth physicochemical analysis of the Franciscan relics was carried out, together with a more careful study $[1 ; 20 ; 27 ; 29 ; 31 ; 32 ; 39]$. Despite the interesting results disclosed by the interdisciplinary approach of that investigation, some problematic aspects related to these objects were left unsolved, proving that the research on this set of historic and artistic documents is far from over.

Today the Franciscan relics are displayed within a showcase in the chapel to the left of the altar, whereas the staurotheke is exhibited as a sort of icon on the top of a temple-shaped tabernacle ${ }^{5}$ standing in a niche above the altar itself. We don't know how the relics were originally located inside the church: neither written sources nor material evidences help us in this respect. The two first statutes of the Cortona Commune, dat-

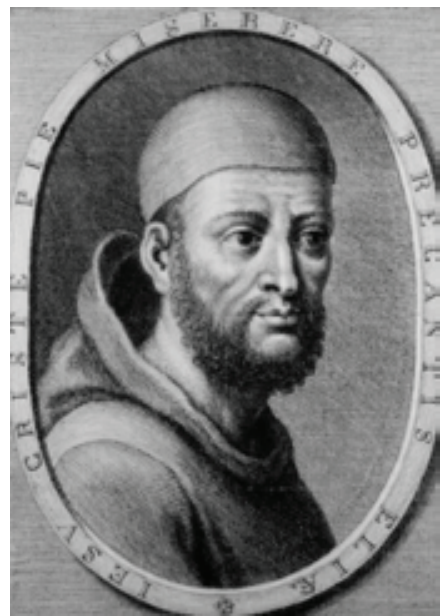

Fig. 1. Carlo Faucci, Francesco Fabrucci. Portrait of Friar Elias. 1755. Franciscan Museum, Roma ing from 1325 and 1411, allude to a "cassa" [2, p. 442] and a "capsa" [26, p. 31] (i.e. a box) respectively, containing the relics "que reposite (...) sunt in ecclesia Sancti Francisci"; a candle was always burning "de die et de nocte" in front of the box. At the beginning of the $20^{\text {th }}$ century, Della Cella $[14$, p. 126] recorded an ebony case with golden ornaments and an inscription in Gothic characters that was held in The Etruscan Academy Museum of the City of Cortona (but unfortunately it has been lost since then). According to him, it might have been specifically created to hold the Byzantine reliquary when the latter was brought in St. Francis church.

However, what is known about the arrival of these objects in Cortona and their relation with Elias? On which basis could the cassock, evangeliary and pillow be connected to the Saint of Assisi?

It is not our goal to discuss issues concerning the authenticity of these relics, but before taking a look at the available sources, it is worth noting that the results of a recent radiocarbon dating method have shown that the cassock is roughly contemporary with the saint's life [32, p. 180].

The earliest reference to the relic of the Holy Cross in the Church of St. Francis can be found in the statute of 1325 mentioned above ${ }^{6}$, whereas the first direct evidence related to the Franciscan relics is very late. It appears indeed in a manuscript dating back to the mid of the $17^{\text {th }}$ century bearing the title Note delle reliquie esistenti nell'Altare dei Sig.ri Corazzi della Città di Cortona, situato nella Chiesa de' RR. PP. Minori Conventuali di detta Città'. All the Franciscan relics can be identified in the list provided by its anonymous author. The cassock was named twice: "Una parte di tonaca di S. Francesco di Assisi" (f. 61r) and again "La Tonaca

\footnotetext{
5 It was produced at the end of the $16^{\text {th }}$ century [34, pp. 220-221].

6 This piece of the True Cross is probably to be found among the relics "omnipotentis Dei" mentioned in the Statute [26, p. 19].

The document (Firenze, Archivio Provincia Toscana O.F.M. Conv., ms. 1,3,3,1, ff. 61r-62v) has been reported by Gatta [20, p. 33]. Anyway, it is very likely that the Franciscan relics were included among the relics "aliorum sanctorum" mentioned in the Statute of 1325 [2, p. 442].
} 
di S. Francesco d'Assisi mancante soltanto di una striscia di fondo" (f. 61v). It seems plausible to think that the latter is the one still belonging to the church of Cortona, since it is perfectly preserved except for a piece of cloth missing from the lower edge ${ }^{8}$ (Ill. 96).

The identification of the two other Franciscan relics appearing in the document poses relatively few problems. The evangeliary (Ill. 97) is referred to as "Un libro dei Vangeli, quale egli [Saint Francis] usava" (f. 61r). Several passages in the Franciscan sources seem to show a preference of the Saint for the breviary together with this other kind of liturgical book, containing those portions of the four Gospels ad usum Missae 9 . Yet, nothing in the relic-book of Cortona indicates or can be related to its previous hypothetical owner - namely Saint Francis. Based on a paleographic analysis carried out on the manuscript, Tristano has, however, suggested that it was probably produced in a scriptorium operating in the area of Tuscany or Umbria between the end of the $12^{\text {th }}$ century and the beginning of the $13^{\text {th }}$ century $[39, \mathrm{pp} .62-63]^{10}$. Further observations concerning its content have been put forward by Millesoli [29], who has come to the conclusion that the formation of the evangeliary of Cortona occurred before 1216, when the reform of the Ordinal envisaged by Innocent III (1198-1216) came into effect [41, p. 41]. Although the Franciscans adopted it as well [40, pp. 280-320], it was not observed in compiling the evangeliary; as a consequence a date earlier than 1216 seems convincing. Is it possible then that it was among the books in use within the first Franciscan community of Cortona settled in Le Celle between 1211 and 1245?

The third relic, recorded in the $17^{\text {th }}$ century list, is the pillow ${ }^{11}$ (Ill. 98), which both d'Alençon $[12$, p. 35; 13] and Sabatier [35, p. 300] assumed to be a donation of Jacoba of Settesoli member of the Frangipane family and close friend of Saint Francis [3] - to the newly constructed Franciscan church of Cortona. Tommaso of Celano's Trattato dei miracoli $(\mathrm{VI}, 38)$ appears to be the first existing source to mention this Roman noblewoman as linked to a pillow [11, p. 536]. Even before a word reached her, she dreamt about Saint Francis' imminent death. Therefore, she set off to reach Assisi taking a pillow with her in order to place it under the head of the dying saint (pulvillum pro capite). Nonetheless, a reference to a red pillow as the one in Cortona appears nowhere. Its case is made of a crimson samite fabric embroidered with interwoven roundels, where animals - lions and eagles - and geometric and phytomorphic motifs take place. Along the outer edges, gallons, each displaying a different ornamental motif (Ill. 99), embellish the pillow. The only exception can be found on the upper side, which exhibits an embroidered inscription that reads as follows: CONfessor domini frANCISCUS AD EThERA MIgRAnS hOC CAPITALE SUUM TENUI SubT(er) CAPUT ALMUM. VALETE I(n) $D$ (omi)NO ET ORATE PRO ME $E^{12}$. How should be this text interpreted? Recent studies have shown this samite pillowcase is not filled with feathers itself, but should be only considered

$8 \quad$ Gatta [20, p. 33] suggests that the other cassock mentioned in the manuscript is the one currently in the Basilica of Santa Croce in Florence.

$9 \quad$ E.g. the expression "Et libros tantum necessarios ad implendum eorum officium possint habere" used in the Regula non bullata (III, 7) [11, p. 64], as already noticed by Bartoli Langeli [7, p. 292]; however, other scholars don't agree with this opinion [33, p. 22].

10 The text of the Evangeliary is written in an Italian Gothic rotunda script probably by a single scribe and has decorated initials in red and blue with filigree [39, pp. 59-61].

11 It is listed as follows: "Un guanciale su cui posò il capo S. Francesco d'Assisi, allorché spirò" (f. 62v).

12 For the reading of the inscription see [27, pp. 124-127]. 
as an external "container", other than the relic. Inside, four more layers can be found indeed ${ }^{13}$. The outermost is a rectangular pillow wrapped in a common linen fabric, which had been folded and stitched to fit the quadrangular shape of the samite case [31, pp. 154-155]. Hence, one might argue the latter is a proper reliquary. Therefore, I would support Sabatier's interpretation of the inscription [36, pp. 299-300] as a writing aiming to certify the authenticity of this pillow-relic. It was written at the time when that donation to the church in Cortona had occurred. Furthermore, it also confirms the donor wanted to reaffirm his role as a direct witness of Saint Francis's life, teaching and death.

According to Magionami, paleographic features of the text suggest that it could be dated to the mid. $13^{\text {th }}$ century in a geographic area of Umbria or Tuscany [27, pp. 127-137]. The samite decorations, instead, have already been classified by Toesca as recalling the Byzantine style [38, pp. 1141-1142]. Conversely, Devoti maintains that they are Sicilian, most likely embroidered in Palermo during the first quarter of the $13^{\text {th }}$ century [15]. In particular, she points out how the ornamental motifs on the two sides of the pillow clearly recall those appearing on some garments belonging to the Insignia of the Holy Roman Empire, created in the Palermitan tiraz both for the Norman sovereigns and Frederick II - i.e. the Coronation Mantle of Roger II, the Alb of King William II and the Gloves of Emperor Frederick II ${ }^{14}$ (Ill. 100).

It follows from the foregoing considerations that we need to ask several questions. On the one hand, the inscription refers to regions of central Italy; on the other, the ornamentation provides definitely dissimilar information: how can such major differences be reconciled? Secondly, these recent investigations have clearly identified both the relic and reliquary, but who was their donor? According to d'Alençon and Sabatier, Jacoba was the person who commissioned this new case and donated it to Elias together with the relic, on occasion of the construction of the church. Magionami has recently discredited this thesis, putting emphasis on the role of Elias instead ${ }^{15}$. Then, it can be useful to reassess the whole question.

At the outset, it is worth mentioning Palei's study that offers a technical analysis of the pillow. According to her findings, the samite fabric, on the one hand, (Ill. 98) and the gallons (Ill. 99), on the other, seem to suggest a different execution, as if they were not created in the same place and period [31, p. 147]. Drawing on Palei's statement, I would like to suggest that an already existing samite cloth was reused and adapted as a reliquary to contain the pillow-relic by the donor of both items. Then they asked the gallons to be made ex novo, to have a twofold function: first, matching two separate pieces of samite cloth by making them two sides of the same new case; secondly, making the embroidered message visible to the Franciscan community of Cortona who received this gift. As it was already mentioned above, previous investiga-

13 The issue concerning the presence of more than one pillow inside each other has not been addressed by scholars hitherto. I cannot take the question into account here, but for practical reasons I will refer to the four items as one.

${ }_{14}$ For these garments see respectively [10;8; 9]. I would furthermore mention the mantle of Saint Lodovico that is currently conserved in Vicenza. This mantle was said to have been created in the $13^{\text {th }}$ century - it is uncertain whether it was made during the beginning or towards the end of the century - by the Sicilian embroiderers working in the royal workshops in Palermo [4].

15 According to Magionami the phrase "Valete in domino et orate pro me" appearing on the pillow may reflect a greeting formula typical of the Minister General of Friars Minor [27, p. 139]. 
tions have suggested relating the samite case with the embroidering tradition of South Italy. At first, this circumstance might lead us to Friar Elias's tight relations with Frederick II, from whom he could have obtained the samite fabric. However, we should also bear in mind the role played by the Frangipane members in the context of the conflict between the Emperor and the Pope in Rome during the first half of the $13^{\text {th }}$ century. It is well known that in 1227 one of the family leaders, i.e. Pietro Frangipane, stood with the Roman imperial party rising against Gregory IX (1227-1241) [37, p. 108]; nonetheless, we don't know whether Jacoba's family sided with the imperial or the papal partisans. Could the ornamental elements tell us anything else? On one side, the eagle is apparently the expression of the imperial potestas; on the other side, the lion has been referred to the coat of arms of the Frangipane family [13, p. 387] bearing two counter-rampant lions facing each other. Yet, those appearing on the pillow are single rampant lions associated to eagles, as if "une sorte de conversation héraldique" had been established between them [36, p. 391]. Is this a reference to a favorable attitude towards the Emperor shown by the Frangipane family on occasion? Or should one consider both animals as recalling the imperial symbolism and power aesthetic implemented by Frederick II [22, pp. 32-33]? Doubts remain, but a persuasive answer to the question together with new historical data concerning Jacoba's family would certainly help us to make new assumptions about the provenance and donor of the pillow.

The name of Elias can be associated to the staurotheke with more certainty. This reliquary (Ill. 95) is an outstanding ivory panel. It was produced in Constantinople during the reign of Nikephoros II Phokas (963-969) [30, pp. 85-86] in order to protect a fragment of the True Cross that is still preserved behind a metal cross added at a later date [25, p. 172]. As I could notice during a recent investigation, a considerable number of holes are to be found along the edges $^{16}$. Based on their distribution and other reasons concerning the function of this object, I recently suggested [26, pp. 22-27] that in its original arrangement this ivory might have been the central panel of a triptych, comparable to the one in Liverpool [21, p. 48]. I have already noticed the metal cross that covers the relic was not part of the original layout, and it is not even the work of a Byzantine artist, rather of a Westerner goldsmith working during the middle or the second half of the $13^{\text {th }}$ century [18, p. 258]. Then, we might assume that the lateral panels had been missing when the reliquary reached the West, and in such a circumstance, the metal cross had been mounted on the ivory, in order to provide a new protection for the relic. We don't know who its donor was, but it might be ascribed to Elias himself who brought the staurotheke in Cortona, according to tradition.

In fact, in 1243, thanks to the relationship of confidence with Frederick II, Elias could receive a formal invitation by the Emperor to go to the East in order to help solving some delicate diplomatic issues (maybe acting as mediator between the Latin Emperor Baldwin II and the Emperor of Nicea John III Vatatzes). According to the $14^{\text {th }}$ century Chronica XXIV Generalium Ordinis Minorum, Elias came back bringing "diversas reliquias et alia donaria" [26, p. 30]. It seems plausible to think that the many relics he acquired on that occasion included the fragment of the True Cross, even though it is impossible to establish which of the two mentioned above emperors offered him these gifts. 
After returning from this long journey ad partes transmarinas, in 1244 Elias decided to settle in Cortona. At the time, he had already been excommunicated, but the community welcomed him and his brothers. In the last years of his life he sought to create a new religious centre in Cortona that would be devoted to Saint Francis and would help keeping his memory alive, thanks to the many relics Elias had placed there. Although the fragment of the True Cross was not straightly referable to Francis' life, it fitted into the overall religious plan set down by Elias. In fact, one may notice that only when matched with the Holy Cross, the evangeliary, cassock, and pillow do reach a deeper and full value, as they become relics belonging to Francis who is perceived as alter Christus ${ }^{17}$. Therefore, in Elia's mind, Cortona was to become a Franciscan centre that could be a sort of alternative to Assisi, which he had helped to found being then estranged from it, because of repeated accusations that had discredited him.

Yet, the works of art and relics Elias collected in Cortona are to be read not only as part of the Franciscan parable, but also according to the role that he played at Frederick II's court and the Mediterranean scene. They shed further light on the closeness of Cortona to the imperial party, while proving that contacts between the Tuscan town and the East must have existed. In such a context, the objects taken into account so far fully represent the primary role of the new Mendicant Orders within the artistic and historical experiences of the $13^{\text {th }}$ century. They also took, on occasion, an active part in spreading culture across the East and the West, as Elias's turbulent life tells us. As a matter of fact, due to his actions in international diplomatic relations of his time, albeit weak and for a short time, Cortona opened up to Italian Southern regions under the control of Frederick II to much wider and culturally richer Mediterranean basin.

Title. Relics in Cortona between Byzantium and Italy: the Case of the Church of St. Francis.

Author. Silvia Leggio - M. A., Ph. D. student. Sapienza University of Rome, Piazzale Aldo Moro, 5, 00185 Roma, Italy. silvia_leggio@hotmail.it

Abstract: The church of St. Francis in Cortona was built in 1245 by one of the most controversial historic figure of the early Franciscan Age, i.e. Friar Elias (ca. 1180-1253), second Minister General of the Order of Friars Minor between 1232 and 1239, supporter of Frederick II and excommunicated by Gregory (1227-1241) in 1240. This church houses an important collection of relics that arrived in the Tuscan town thanks to the effort of Elias himself: a fragment of the Holy Cross, preserved in the renowned Byzantine ivory staurotheke (second half of the $10^{\text {th }}$ century) that he probably acquired during a diplomatic mission to the East, and Francis' evangeliary, cassock and mortuary pillow. The latter was said to have been donated to Elias and to the newly constructed church in Cortona by the Roman noblewoman Jacoba of Settesoli, member of the Frangipane family and close friend of Saint Francis.

Despite their importance as historic and artistic documents telling us both about the role of Elias as intermediate between Byzantium and Cortona and his deep and intimate connection with Saint Francis, these items have been mostly neglected by scholars hitherto. Along with providing an overview on this little-known set of relics and reliquaries, this paper draws attention to a number of problematic issues left unsolved, mostly concerning the pillow, its provenance and its donor.

Keywords: relics; reliquary; Friar Elias; Saint Francis; Frederick II; Jacoba of Settesoli; Cortona; St. Francis church; Byzantium.

Название статьи. Реликвии церкви Святого Франциска в Кортоне: между Византией и Западом.

Сведения об авторе. Леджио Сильвия - магистр, аспирант. Римский университет Сапиенца, площадь Альдо Моро, 5, Рим, Италия, 00185. silvia_leggio@hotmail.it

17 For an overview about the experience of the cross of Christ in Saint Francis' life, as reflected in his writings see [23]. 
Аннотация. Церковь Св. Франциска в Кортоне была построена в 1245 г. одним из очень неоднозначных деятелей начала францисканской эпохи Илией Кортонским (ок. 1180-1253) - вторым генеральным министром Ордена младших братьев (1232-1239), сторонником императора Фридриха II, впоследствии отлученным от церкви Григорием IX (1227-1241). В церкви имеется значительное собрание реликвий, которые оказались в этом тосканском городе благодаря его усилиям. Среди них - частица Животворящего креста Господня, хранимая в знаменитой византийской ставротеке из слоновой кости (втор. пол. Х в.), которую Илия Кортонский приобрел, вероятно, во время посольства на Восток, а также евангелиарий, сутана святого Франциска и подушечка с его смертного одра. Последняя, по преданию, была преподнесена Илии для недавно возведенной церкви в Кортоне римской знатной дамой Якопой Сеттесоли, которая была близком другом святого Франциска.

Эти памятники, столь значимые и в историческом, и в художественном отношении, свидетельствуют о роли Илии как посредника между Виантией и Кортоной и его глубокой связи со святым Франциском. Однако они до сих пор оставались вне поля зрения исследователей. Настоящая работа содержит обзор этих малоизвестных реликвий и реликвариев, а также поднимает ряд по сей день неразрешенных вопросов, связанных прежде всего с подушечкой, ее донатором и провенанс.

Ключевые слова: реликвии; реликварий; Илия Кортонский; император Фридрих II; Якопа Сеттесоли; Кортона; святой Франциск и францисканцы; Византия.

\section{References}

1. Allegria S. Il libro del Santo, il Santo del libro: l'Evangelistario di Cortona. Il calendario. Léredità del padre. Le reliquie di San Francesco a Cortona. Padova, Edizioni Messaggero Publ., 2007, pp. 93-112 (in Italian).

2. Allegria S.; Capelli V. (eds.) Statuto del Comune di Cortona (1325-1380). Firenze, Olshki Publ., 2014. 564 p. (in Italian).

3. Aubert R. Frangipane (Jacqueline). Dictionnaire d'histoire et de géographie ecclésiastiques, vol. 18. Paris, Letouzey et Ané Publ., 1977, pp. 1001-1002 (in French).

4. Avagnina M. E. Piviale con volatili addossati. Nobiles Officinae: perle, filigrane e trame di seta dal Palazzo Reale di Palermo: Catalogue, vol. 1. Catania, Maimone Publ., 2006, pp. 391-393 (in Italian).

5. Barone G. Da Frate Elia agli spirituali. Milano, Biblioteca francescana Publ., 1999. 220 p. (in Italian).

6. Barone G. Elia di Assisi (da Cortona). Federico II: enciclopedia fridericiana, vol. 1. Roma, Istituto dell'Enciclopedia Italiana Publ., 2005, pp. 507-509 (in Italian).

7. Bartoli Langeli A. I libri dei frati. La cultura scritta dell'Ordine dei Minori. Francesco d'Assisi e il primo secolo di storia francescana. Torino, Einaudi Publ., 1997, pp. 283-305 (in Italian).

8. Bauer R. Alba di Guglielmo II. Nobiles Officinae: perle, filigrane e trame di seta dal Palazzo Reale di Palermo: Catalogue, vol. 1. Catania, Maimone Publ., 2006, pp. 55-59 (in Italian).

9. Bauer R. Guanti. Nobiles Officinae: perle, filigrane e trame di seta dal Palazzo Reale di Palermo: Catalogue, vol. 1. Catania, Maimone Publ., 2006, pp. 69-71 (in Italian).

10. Bauer R. Tunicella blu (dalmatica). Nobiles Officinae: perle, filigrane e trame di seta dal Palazzo Reale di Palermo: Catalogue, vol. 1. Catania, Maimone Publ., 2006, pp. 51-53 (in Italian).

11. Caroli E. (ed.) Fonti francescane: scritti e biografie di san Francesco d'Assisi, cronache e altre testimonianze del primo secolo francescano, scritti e biografie di santa Chiara d'Assisi, testi normativi dell'Ordine francescano secolare. Padova, Editrici francescane Publ., 2004. 2365 p. (in Italian).

12. D’Alençon É. Frère Jacqueline. Recherches Historiques sur Jacqueline de Settesoli. Lamie de Saint François. Paris, Librairie S. François d’Assise Publ., 1927. 65 p. (in French).

13. D’Alençon É. Une relique de Saint François. Annales Franciscaines, 1902, vol. 21, pp. 385-387 (in French).

14. Della Cella A. Cortona antica. Cortona, Tipografia Sociale Publ., 1900. 315 p. (in Italian).

15. Devoti D. Il Cuscino Funebre di San Francesco. Tesori dalle chiese di Cortona: Catalogue. Firenze, S. P. E. S. Publ., 1987, pp. 1-8 (in Italian).

16. Docci M. S. Francesco a Cortona: rilievo, analisi storica e nuovi contributi. Opus: quaderno di storia, architettura, restauro, 1995-1996, vol. 4, pp. 135-152 (in Italian).

17. Elia di Cortona tra realtà e mito, Atti dell'incontro di studio. Cortona, 12-13 luglio 2013. Spoleto, Fondazione Centro Italiano di Studi sull'Alto Medioevo Publ., 2014. 250 p. (in Italian).

18. Gaborit-Chopin D. Icon with Lapis Lazuli Crucifixion Medallion. The Treasury of San Marco, Venice: Catalogue. Milano, Olivetti Publ., 1984, pp. 258-268. 
19. Garzi G. La patria di Frate Elia: contributo agli studi francescani. Cortona, Alari Publ., 1908. 27 p. (in Italian).

20. Gatta S. Uno sguardo alle fonti. L'eredità del padre. Le reliquie di San Francesco a Cortona. Padova, Edizioni Messaggero Publ., 2007, pp. 29-37 (in Italian).

21. Gibson M. The Liverpool Ivories: Late Antique and Medieval Ivory and Bone Carving in Liverpool Museum and the Walker Art Gallery. London, HMSO Publ., 1994. 121 p.

22. Guzzo C. Aquile, leoni, tessuti e colori: Federico II di Svevia e l'estetica del potere. Federico II: le nozze di Oriente e Occidente. L'età federiciana in terra di Brindisi. Atti del Convegno di studi (Brindisi, Palazzo Granafei-Nervegna, 8-9-14 novembre 2013). Brindisi, Pubblidea Publ., 2014, pp. 27-41 (in Italian).

23. Iammarrone G. La croce in san Francesco e nel primo francescanesimo. La croce: iconografia $e$ interpretazione (secoli I-inizio XVI). Atti del convegno internazionale di studi (Napoli, 6-11 dicembre 1999), vol. 2. Napoli, Elio de Rosa Publ., 2007, pp. 369-402 (in Italian).

24. Inga G. Gli insediamenti mendicanti a Cortona. Storia della città, 1978, vol. 9, pp. 44-55 (in Italian).

25. Klein $H$. Die Elfenbein-Staurothek von Cortona im Kontext mittelbyzantinischer Kreuzreliquiarproduktion. Spätantike und byzantinische Elfenbeinbildwerke im Diskurs. Wiesbaden, Reichert Publ., 2008, pp. 167-190 (in German).

26. Leggio S. La stauroteca eburnea della chiesa di S. Francesco a Cortona. Arte Medievale, 2014, vol. 4, pp. 3-34 (in Italian).

27. Magionami L. Hoc capitale tenui. Il cuscino di s. Francesco a Cortona e la sua iscrizione. Léredità del padre. Le reliquie di San Francesco a Cortona. Padova, Edizioni Messaggero Publ., 2007, pp. 121-140 (in Italian).

28. Mancini G. Cortona nel Medio Evo. Firenze, Carnesecchi Publ., 1897. 396 p. (in Italian).

29. Millesoli G. M. Il libro del Santo, il Santo del libro: l'Evangelistario di Cortona. Il testo. Leredità del padre. Le reliquie di San Francesco a Cortona. Padova, Edizioni Messaggero Publ., 2007, pp. 77-92 (in Italian).

30. Oikonomides N. The Concept of 'Holy War' and Two Tenth-Century Byzantine Ivories. Peace and War in Byzantium: Essays in Honor of George T. Dennis. Washington, Catholic University of America press Publ., 1995, pp. 62-86.

31. Palei G. Hoc capitale tenui. Il cuscino: tecnica di esecuzione e materiali. Léredità del padre. Le reliquie di San Francesco a Cortona. Padova, Edizioni Messaggero Publ., 2007, pp. 141-156 (in Italian).

32. Palei G. La tonaca di san Francesco a Cortona. L'eredità del padre. Le reliquie di San Francesco a Cortona. Padova, Edizioni Messaggero Publ., 2007, pp. 169-180 (in Italian).

33. Paolazzi C. I frati minori e i libri: per l'esegesi di "ad implendum eorum officium" (Rnbu III, 7) e "nescientes litteras" (Rnbu III, 9; Rebu X, 7). Archivium Franciscanum Historicum, 2004, vol. 97, pp. 3-59 (in Italian).

34. Pichi S. Splendori del Cinquecento. Arte in terra d'Arezzo. Il Cinquecento. Firenze, Edifir Publ., pp. 217226 (in Italian).

35. Refice P. Per un Medioevo globale: reliquie in terra d'Arezzo. Arte in terra d'Arezzo. Il Medioevo. Firenze, Edifir Edizioni Publ., 2010, pp. 153-162 (in Italian).

36. Sabatier P. Examen critique des récits concernants la visite de Jacqueline de Settesoli à Saint François. Opuscules de Critique Historique, 1910, vol. 15, pp. 289-331 (in French).

37. Thumser M. Rom und der römische Adel in der späten Stauferzeit. Tübingen, Niemeyer Publ., 1995. 425 p. (in German).

38. Toesca P. Storia dellarte italiana. Il Medioevo. Torino, Unione tipografico-editrice torinese Publ., 1927. 462 p. (in Italian).

39. Tristano C. Il libro del Santo, il Santo del libro: l'Evangelistario di Cortona. Il libro. L'eredità del padre. Le reliquie di San Francesco a Cortona. Padova, Edizioni Messaggero Publ., 2007, pp. 41-75 (in Italian).

40. Van Dijk S. J. P.; Walker J. H. The Origins of the Modern Roman Liturgy: The Liturgy of the Papal Court and the Franciscan Order in the $13^{\text {th }}$ century. Westminster, Newman Press Publ., 1960. 586 p.

41. Van Dijk S. J. P.; Walker J. H. The Ordinal of the Papal Court from Innocent III to Boniface VIII and Related Documents. Fribourg, The University Press Publ., 1975. 707 p. 


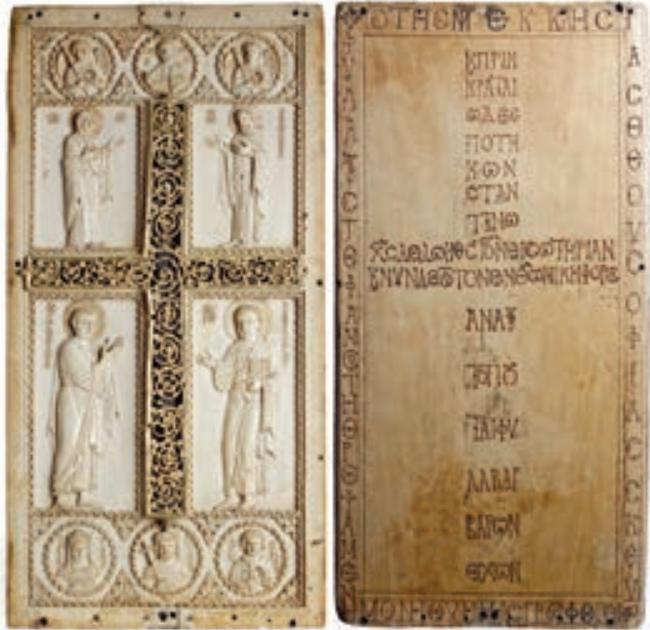

Ill. 95. Byzantine artist. Reliquary of the True Cross. 963-969. St. Francis church, Cortona

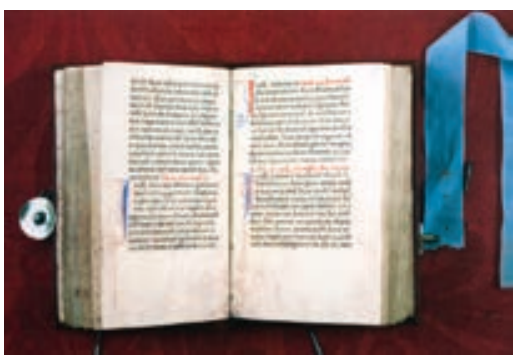

Ill. 97. Saint Francis' Evangeliary. Italian scriptorium. End of the $12^{\text {th }}$ century - beginning of the $13^{\text {th }}$ century. St. Francis church, Cortona
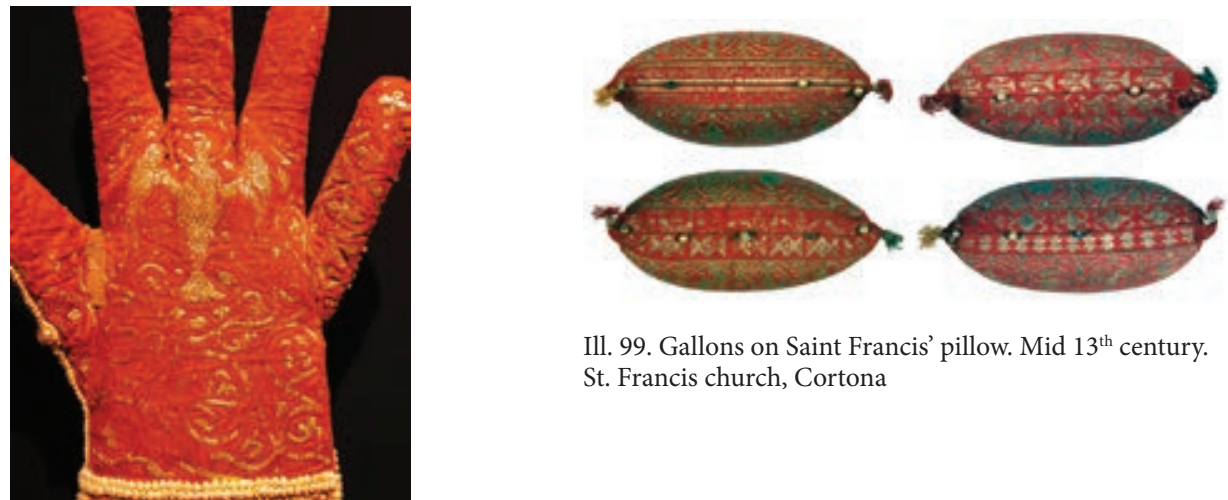

Ill. 99. Gallons on Saint Francis' pillow. Mid $13^{\text {th }}$ century. St. Francis church, Cortona
Ill. 96. Saint Francis' cassock. $12^{\text {th }}-13^{\text {th }}$ century.

St. Francis church, Cortona.

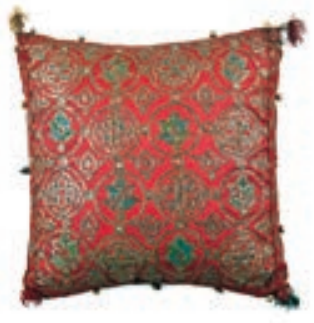

Ill. 98. Saint Francis' pillow. St. Francis church, Cortona

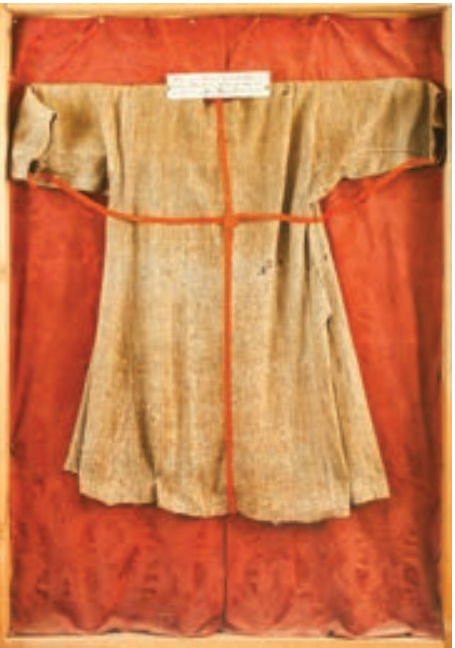

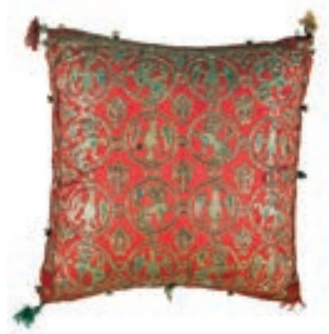

Ill. 100. Frederick II's gloves. Before 1220 .

Kunsthistorisches Museum,

Weltliche Schatzkammer, Wien 